\title{
DESIGNING A FRAMEWORK TO DESIGN A BUSINESS MODEL FOR THE 'BOTTOM OF THE PYRAMID' POPULATION
}

\author{
T. ver Loren van Themaat $^{1}$, C.S.L. Schutte ${ }^{2 *}$, D. Lutters $^{3} \&$ D. Kennon ${ }^{4}$ \\ Department of Industrial Engineering \\ University of Stellenbosch, South Africa \\ ${ }^{2}$ corne@sun.ac.za,3d.lutters@utwente.nl, ${ }^{3}$ dkennon@sun.ac.za
}

\begin{abstract}
This article presents a framework for developing and designing a business model to target the 'bottom of the pyramid' (BoP) population. Using blue ocean strategy and business model literature, integrated with research on the BoP, the framework offers a systematic approach for organisations to analyse and understand all aspects of the BoP and their environment, and then design a business model that minimises the risk of failure and fulfils the core requirements of the BoP.
\end{abstract}

A case study on Capitec Bank demonstrates how the framework can be applied to the real world. The case study shows the practical examples that Capitec uses to target the BoP successfully, and the logic behind these actions. Further validation was done through interviews with experts in the relevant fields used in this study.

\section{OPSOMMING}

Hierdie artikel stel ' $n$ strategie vir die ontwikkeling en ontwerp van ' $n$ besigheidsmodel vir die 'bottom of the pyramid' (BoP) populasie voor deur behulp van ' $n$ raamwerk. Deur die 'blue ocean' strategie- en besigheidsmodel-literatuur te gebruik, sowel as deur navorsing oor die BoP te doen, kan die raamwerk ' $n$ sistematiese benadering vir ' $n$ organisasie gee om eers alle aspekte van die BoP en hul omgewing te ontleed en te verstaan, en daarvolgens ' $n$ besigheidsmodel te ontwerp wat die risiko van mislukking en aan die kern vereistes van die BoP voldoen.

'n Capitec Bank gevallestudie illustreer hoe die raamwerk toegepas kan word in die praktyk. Die gevallestudie toon die praktiese voorbeelde wat Capitec gebruik om suksesvol die BoP te betree, met die motiverende logika. Verdere validasie was gedoen dmv onderhoude met kenners in die verwante velde aangeraak in die studie.

\footnotetext{
${ }^{1}$ The author was enrolled for a MSc.Eng(Engineering Management) degree in the Department of Industrial Engineering, University of Stellenbosch

*Corresponding author

${ }^{4}$ The author is enrolled for a PhD at the Department of Industrial Engineering, University of Stellenbosch
} 


\section{INTRODUCTION}

The 'bottom of the pyramid' (BoP) population is a large and currently untapped market in South Africa. The BoP often do not have easy access to products and services, because most organisations consider the challenges of the BoP to be overwhelming and unconquerable. Organisations face constant pressure to increase their market share and profits and to improve their performance in the current aggressive environment. To retain their competitiveness, they have to look at unconventional and alternative markets.

By recognising the BoP as a potential emerging market, organisations can increase their market share or enter new markets, creating benefits for organisations and the BoP alike. In the Sunday Times Business Times Top 100 Companies Survey for 2010, where companies are listed according to the wealth created for their shareholders, the top 10 are all companies who have successfully targeted the BoP. Capitec topped this list with 51.23 per cent compound interest over the last five years [13].

The goal of this article is to create awareness of this BoP market, give an organisation a framework through which to think, and then design a basic business model to target the BoP. The framework will give an organisation a structured method for looking at all the different elements of the business model, and seeing how they must be designed to put an organisation in the best possible position to target the BoP.

\subsection{Targeting the bottom of the pyramid (BoP)}

C.K. Prahalad has defined individuals living below $\$ 1,500$ per year, which is considered the minimum amount necessary to sustain a decent life, as the Bottom of the Pyramid (BoP) population [1]. More than two-thirds of the world's population fall into this category. Figure 1 shows the spread of wealth among the world's population.

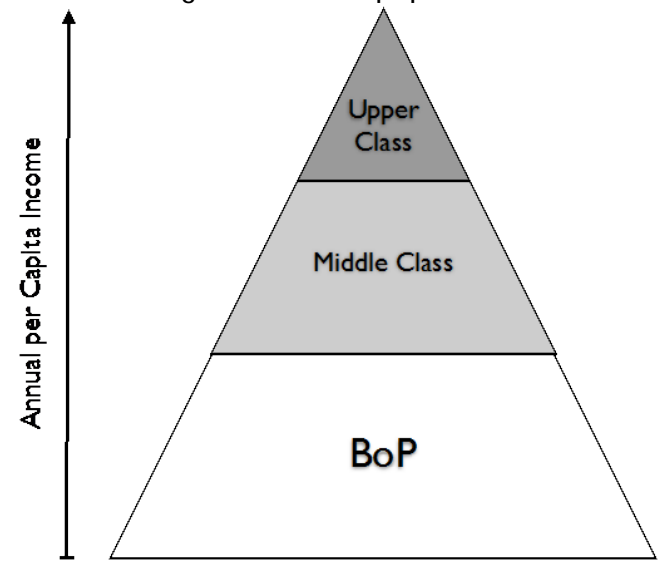

Figure 1: The world economic pyramid (adapted from [1,2])

Anderson and Billou [11] observe that organisations that have achieved success in the BoP are normally those who have developed an approach that supplied the Four $\mathbf{A}^{\prime} \mathbf{s}$ [11]:

- Acceptability: the product or service must have exceptional utility, and must be adapted to the unique needs of the BoP market and their distributors.

- $\quad$ Availability: the degree to which a product or service can be obtained and accessed by the BoP.

- $\quad$ Awareness: the extent to which the BoP is aware of a specific product, service, or brand name.

- Affordability: the extent to which the BoP can bear the expense of a product or service. 
The Four A's are the core requirements of the BoP - the crucial and necessary factors that have to be addressed in the business model in order to target the BoP [11].

Many industries have not recognised the BoP as a viable market. They often ignore and neglect the BoP, preferring to target the middle- and upper-class niche markets because they are better understood and give organisations higher profit margins. In those industries, the BoP are considered to be 'non-consumers' [7], and they are currently not directly targeted by business. Therefore, the segment of the BoP that is non-consumers can be considered a possible 'blue ocean'.

\subsection{Blue ocean strategy}

Blue oceans represent all those industries that are not in existence today. The blue ocean strategy, developed by Kim and Mauborgne [8], locates new customers and creates new markets by pushing the boundaries of existing industries. The corresponding prospects are defined by untapped market space, demand creation, and the opportunity for highly profitable growth [8]. Blue oceans are currently unknown and completely untainted by competition. The BoP has the potential to be a very lucrative blue ocean.

Michael Porter stated that every organisation must decide whether its strategy will focus on differentiation or on cost leadership to gain advantage over the competition [9]. It was always believed that organisations had two choices: either they created average value at low costs for their customers, or they added greater value at higher costs. Value innovation is the cornerstone of blue ocean strategy [8], and it rejects the fundamental principle that there must be a trade-off between low-cost and value - both of which are essentials that the BoP desperately needs.

Product innovation is a difficult challenge that even the best organisations often get wrong - either because they introduce their product at the wrong time, or because they introduce it at a price that most customers do not find compelling. A new product must offer customers benefits and outstanding utility at a price that is affordable to them, and the organisation must realise a financial result that is in line with their strategy [10]. This, among other things, makes the BoP in South Africa a potential blue ocean.

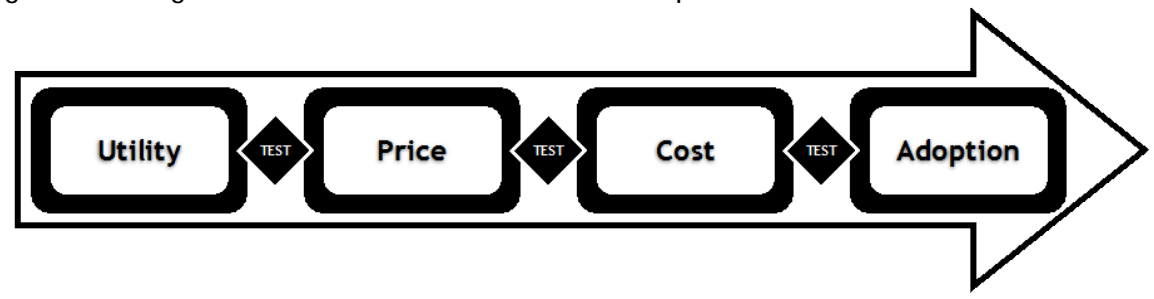

Figure 2: Strategic sequence [10]

The strategic sequence developed by Kim and Mauborgne $[10,8]$ assists an organisation to improve the commercial value of concepts. It also gives organisations a specific order that they must follow to validate their concept for commercial success. By following this order, Kim and Mauborgne claim that some of the business model risk can be reduced. The sequence is utility, price, cost, and adoption (as shown in Figure 2), and is explained in more detail below:

1. Creating exceptional utility: The first step in getting the strategic sequence right is to make sure that the product offers exceptional utility to the customer. This step evaluates the likelihood that customers and non-customers will be attracted to the new product. When a new product/service is designed, the organisation must ensure that the product/ service attracts its target market [10].

2. Setting the strategic price: Not only must an organisation ensure that buyers wish to buy the product, they must also have the ability to pay for it. To ensure that an organisation achieves satisfactory revenue, it has to set its strategic price at the right level to attract the masses [8]. 
3. Target costing: Once an organisation has set its strategic price, it needs to consider the amount of profit it wants to make. Kim and Mauborgne say that "to maximize the profit potential of a blue ocean idea, a company should start with the strategic price and then deduct its desired profit margin from its price to arrive at the target cost" [8]. This is absolutely essential to ensure that the cost structure is profitable and difficult to imitate. Reaching target costs ensures that an organisation earns sufficient profits. Target costing addresses the profit side of the business model [8].

4. Overcoming adoption hurdlesi: Innovation brings about change, and this can threaten the way things are for the three most important stakeholders of an organisation: the employees, the partners, and the general public. It is important that open and transparent discussions about the changes are held between the stakeholders. The way to overcome most fears, including those caused by innovation and change, is to ensure that the fearful are educated [10].

Kim and Mauborgne developed this sequence as an assessment tool to test potential blue ocean ideas. In the context of designing a business model, it can help with the design and evaluation of the business model, and ensure that any risk of failure is minimised [10].

Most organisations are unable to be innovative beyond their own business models [5]. Expanding into the BoP requires the right business model to be able to bring affordable technology and available networks to the BoP, and to bring the few expensive options to everyone at an affordable price.

\subsection{Business models}

A business model is the logic for creating value: It demonstrates which activities and approaches can equip the organisation to be successful [3]. It can also be described as "a diagram or blueprint of how a business works to provide value to its target market and produce a profit" [4]. For Osterwalder and Pigneur [5], "a business model describes the rationale of how an organisation creates, delivers and captures value".

A very easy and convenient tool to help organisations to design a business model was devised by Osterwalder and Pigneur [5]. It is called 'the business model canvas', and it gives organisations a chance to brainstorm and conceptualise the model of their organisation, and to analyse the models of competitors and other organisations that can then be benchmarked. Osterwalder [6] studied the business model literature, and used the contributions of different authors to construct this new model, which has nine components. By analysing the organisation within the context of these nine components, a specific business model can be compiled that helps managers to understand and describe the business logic of their organisation [6].

For the purpose of this research, Osterwalder and Pigneur's business model canvas ${ }^{\mathrm{ii}}$ was slightly adapted to target the BoP more effectively. The adapted nine building blocks of the business model canvas are illustrated in Figure 3.

Organisations that want to include the BoP in their target market must rethink their business model to ensure that it fulfills the core requirements of the BoP. The $4 \mathrm{~A}^{\prime}$ s serve as tests that an organisation can take to determine whether their business concept will be satisfactory and accepted by the BoP population. When an organisation wants to design a new business model and minimise the risk of failure, it can be very helpful to design it using the strategic sequence of utility, price, and cost. Any adoption hurdles can be seen as constraints that affect this sequence.

\footnotetext{
i Adoption will not be used in this study, because it is concerned with the implementation stage of an idea. This study focuses on the planning stage.

ii For the original business model canvas, see Osterwalder and Pigneur's book, Business model generation [5].
} 


\begin{tabular}{|c|c|c|c|c|c|}
\hline \multirow{2}{*}{$\begin{array}{l}\text { Key Partnerships } \\
\text { Is the network of } \\
\text { suppliers and } \\
\text { partners the } \\
\text { organisation can use } \\
\text { that provides more } \\
\text { efficient, affordable } \\
\text { services and } \\
\text { infrastructure. }\end{array}$} & $\begin{array}{l}\text { Key Activities } \\
\text { Is all the activities } \\
\text { including the value } \\
\text { chain that ensures } \\
\text { that the business } \\
\text { model works }\end{array}$ & \multirow{2}{*}{\multicolumn{2}{|c|}{$\begin{array}{l}\text { Value Proposition } \\
\text { Is the product/service } \\
\text { that the organisation } \\
\text { offers the BoP. It also } \\
\text { considers how the } \\
\text { organisation will } \\
\text { make the product/ } \\
\text { service fit into the } \\
\text { lifestyle and } \\
\text { circumstances of the } \\
\text { BoP, ensuring that } \\
\text { they accept the } \\
\text { offering. }\end{array}$}} & $\begin{array}{l}\text { Channels } \\
\text { Shows how the BoP } \\
\text { will be reached } \\
\text { Marketing and } \\
\text { Distribution. }\end{array}$ & \multirow{2}{*}{$\begin{array}{l}\text { Customer } \\
\text { Shows how the } \\
\text { organisation will } \\
\text { immerse themselves } \\
\text { in the BoP to gain } \\
\text { understanding and } \\
\text { insight on how to } \\
\text { overcome the } \\
\text { constraints and fulfill } \\
\text { the BoP's core } \\
\text { requirements. }\end{array}$} \\
\hline & $\begin{array}{c}\text { Key Resources } \\
\text { Is all the resources } \\
\text { needed to ensure the } \\
\text { business model } \\
\text { works }\end{array}$ & & & $\begin{array}{l}\text { Customer Interfaces } \\
\text { The relationship and } \\
\text { interaction between } \\
\text { BoP and the } \\
\text { organisation }\end{array}$ & \\
\hline \multicolumn{6}{|c|}{$\begin{array}{l}\text { Cost Structure } \\
\text { Shows how the organisation ensures that the target cost } \\
\text { is reached to make a healthy profit. This building block } \\
\text { describes all the costs an organisation occurs in } \\
\text { delivering the value proposition. }\end{array}$} \\
\hline
\end{tabular}

Figure 3: The business model canvas for the BoP (adapted for the purpose of this article from Osterwalder and Pigneur's business model canvas [5])

\subsection{Combining the business model and the strategic sequence}

By combining the business model canvas (components) with the strategic sequence for a blue ocean strategy, an arrangement can be created to build and test the components of the business model. This helps to validate the concept and to minimise risk. Figure 4 shows the relationship between the business model canvas and the blue ocean strategic sequence, as well as the order in which the business model canvas components must be designed to comply with the strategic sequence.

Strategic Sequence

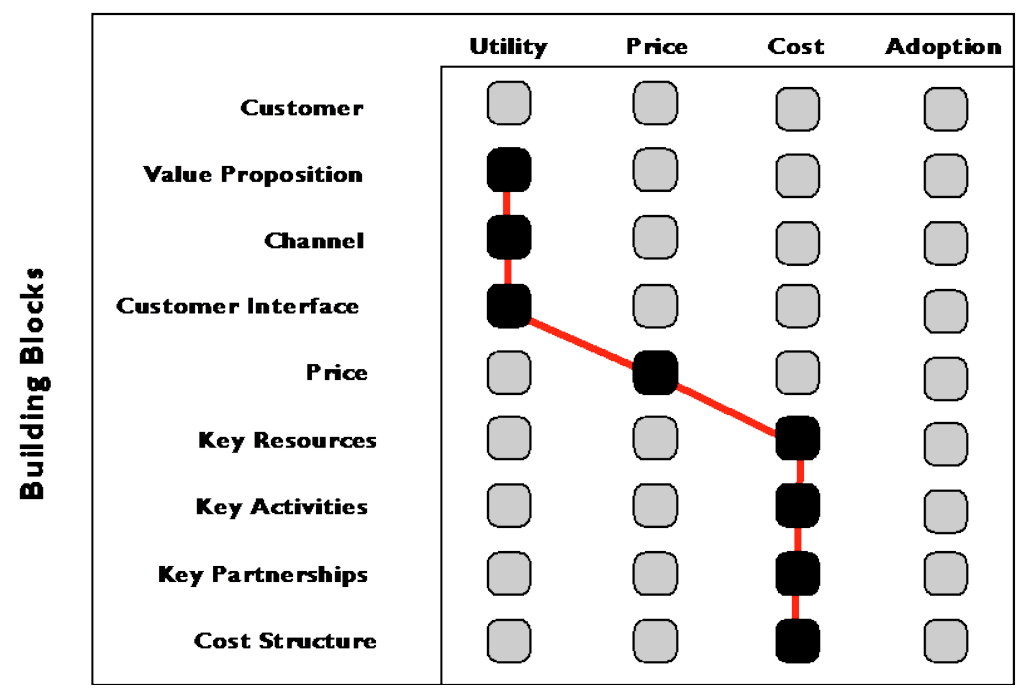

Figure 4: Combining the strategic sequence with the business model canvas building blocks

Next, Figure 5 shows the process that an organisation must follow to rethink its business model. The first step, which is not addressed in the strategic sequence, is the customer component of the business model canvas. This step involves every aspect relating to the customer, such as market research and market strategy. 


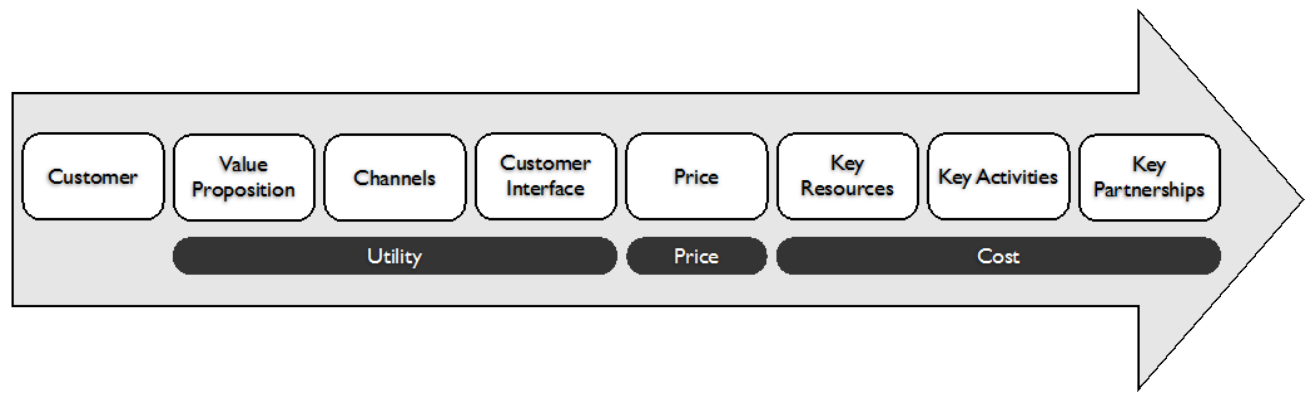

Figure 5: The process the BoP framework must follow

When an organisation wants to design a business model to expand into the BoP market, there are certain prerequisites that have to be met to ensure a higher chance of success. These prerequisites make the BoP different from any other market.

\section{THE FRAMEWORK TO DESIGN A BUSINESS MODEL FOR THE BOP}

There are two main tests that an organisation's BoP business model must pass to ensure the highest possible viability. The concept must first pass the $4 \mathrm{~A}^{\prime} \mathrm{s}$. This ensures that the product or service is tailored and acceptable to the BoP. The second test is the strategic sequence. This ensures that the organisation will be profitable when targeting the BoP.

Each component of the business model canvas must therefore fulfill either the core requirements of the BoP (the $4 \mathrm{~A}^{\prime} \mathrm{s}$ ) or the core requirements of the organisation (strategic sequence) as a minimum, to ensure that it is viable. The tests that each component must pass are presented in Table 1. It is important to note that when an organisation designs a business model, each component must first pass its test before the organisation can continue with designing the next component in the sequence. If the test or core requirement is not achieved, the organisation must rethink that component until a solution is found. If no solution is found, the business model will not be feasible, and might carry unnecessary risk.

Table 1: Testing the business model components for viability (adapted from $[5,8,11]$ )

\begin{tabular}{|c|c|c|}
\hline \multirow[b]{2}{*}{ Component } & \multicolumn{2}{|c|}{ Test } \\
\hline & $\begin{array}{l}\text { Core requirement } \\
\qquad\left(4 \mathrm{~A}^{\prime} \mathrm{s}\right)\end{array}$ & Strategic sequence \\
\hline \multicolumn{3}{|l|}{ Customer (research) } \\
\hline \multicolumn{3}{|c|}{ Window of opportunity } \\
\hline Value proposition & Acceptability & Utility \\
\hline Channels & $\begin{array}{l}\text { Availability and } \\
\text { awareness }\end{array}$ & Utility \\
\hline Customer interface & Acceptability & Utility \\
\hline \multicolumn{3}{|c|}{ Price element } \\
\hline Price & Affordability & Price \\
\hline \multicolumn{3}{|c|}{ Infrastructure element } \\
\hline Key activities & $4 \mathrm{~A}^{\prime} \mathrm{s}$ & Cost \\
\hline Key resources & $4 \mathrm{~A}^{\prime} \mathrm{S}$ & Cost \\
\hline Key partnerships & $4 \mathrm{~A}^{\prime} \mathrm{s}$ & Cost \\
\hline
\end{tabular}

The viability of each component, as well as the business model as a whole, must be assessed during design. After the development of each component, the organisation must consider the solution and decide whether the idea is feasible. If the solution is not viable, the design process must be halted until a realistic solution can be found. 


\subsection{Customer and strategy element}

Before an organisation can start designing its business model, it is vital that it understand the needs and core requirements of the BoP. This component also includes some strategising on how to approach the whole process.

\subsection{The window of opportunity for the BoP}

The value proposition, channels, and customer interface components fall under 'utility'. These three components form the window of opportunity. The mission of the components in the window of opportunity is to ensure that the customer receives exceptional utility from the products and services the organisation offers, to capture the mass of the market.

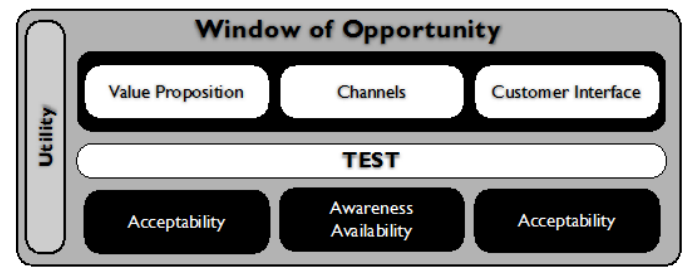

Figure 6: The window of opportunity for the BoP

The window of opportunity looks at whether the organisation can fulfill the first three of the $4 \mathrm{~A}^{\prime} \mathrm{s}$ : acceptability, availability, and awareness. An organisation must remember that if it cannot provide the BoP with the products and services that fulfill these requirements, the business model is not viable.

\subsection{The price element for the BoP}

The organisation must look externally to the market to determine the right price. The price that an organisation charges for a product must not only be affordable, it must give the BoP value for money. It is important that organisations set their price so that the biggest possible segment of the population can afford their value proposition.

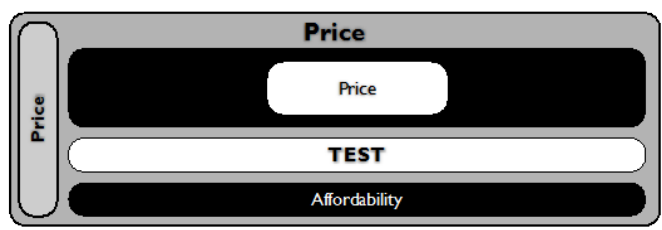

Figure 7: The pricing element for the BoP

Up to this point, the focus has been on attracting large volumes by fulfilling the core requirements of the target market. But to ensure that an organisation still makes a healthy profit, it needs to keep its costs as low as possible. The profit margins at the BoP are very low, so it is important to ensure that large volumes are obtained.

\subsection{The infrastructure element for the BoP}

The key resources, key activities, and key partnerships are the infrastructure components; they fall under the cost step because they affect the costs incurred by an organisation. They are called the infrastructure.

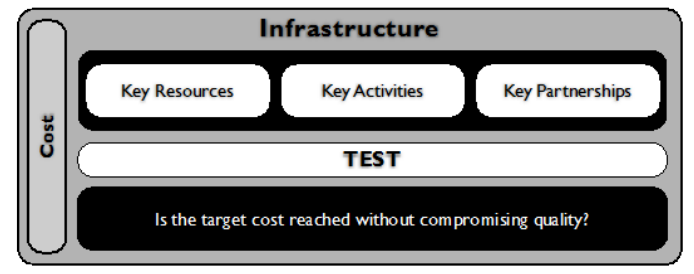

Figure 8: The infrastructure element for the BoP 
The infrastructure element must ensure that the organisation reaches its target cost without compromising quality. The last three steps therefore look at the organisation's infrastructure needs, and how to lower costs to reach the target. The organisation must bring its costs down while not compromising the quality of its value proposition or revenue earning capacity.

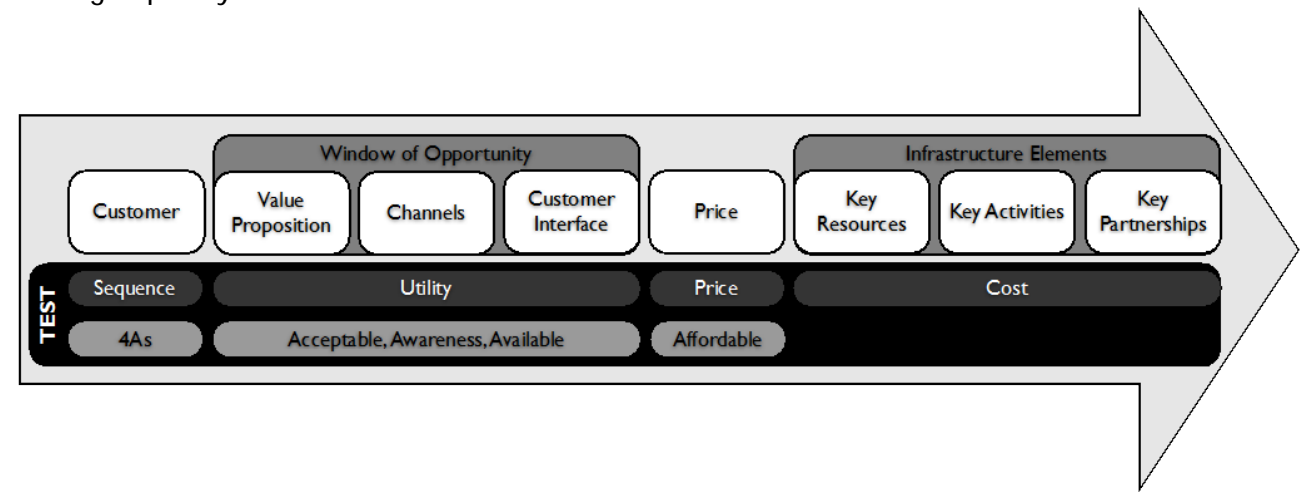

Figure 9: The tests that the components have to pass at each step of the BoP framework

Figure 9 shows the systematic sequence that the BoP framework follows, as well as the tests that must be passed at each step to ensure that the business model is viable and to reduce the risk of failure.

One organisation that has successfully managed to target the BoP is Capitec Bank. It changed the industry by recognising the BoP as a viable market. Many other organisations (banks and others) are following suit. Capitec targeted a market that was deemed unprofitable by other banks, thus identifying a blue ocean.

\section{CAPITEC'S BUSINESS MODEL DEVELOPMENT}

Capitec Bank was established in South Africa in March 2001, and was listed on the J ohannesburg Stock Exchange on 18 February 2002 [12]. It has designed its business model to draw the previously unbanked into the banking sector, while still being profitable.

Capitec Bank will be used as an example to illustrate how the BoP framework can be used to target the BoP successfully. Capitec has designed its products, processes, practices, and premises in a way that is satisfactory to the BoP, and manages to draw a large volume of customers. Its marketing, distribution, and product design is innovative, and often goes against conventional wisdom. Capitec's version of the $4 A^{\prime} s$ is simplicity, personal service, accessibility, and affordability, which it customised for its target market.

After a more detailed analysis of the Capitec model, the four actions framework ${ }^{i}$ [14] (a tool used in blue ocean strategy) can be used to identify where Capitec made the most dramatic changes to its business model to differentiate it from other banks. This can be seen in Table 2.

Capitec's business model will be discussed using the sequence shown in Figure 10. Each step will be explained using the Capitec case as an illustrating example.

\footnotetext{
' Kim and Mauborgne [8] created the four actions framework to overcome the compromises that industry forces customers to make. Cost savings are made by eliminating and reducing some feature that the industry takes for granted and that doesn't add value; and the value for the customer is increased by raising and creating elements that the industry has never offered before [8].
} 
Table 2: Capitec's four action framework (adapted from [12, 15-19])

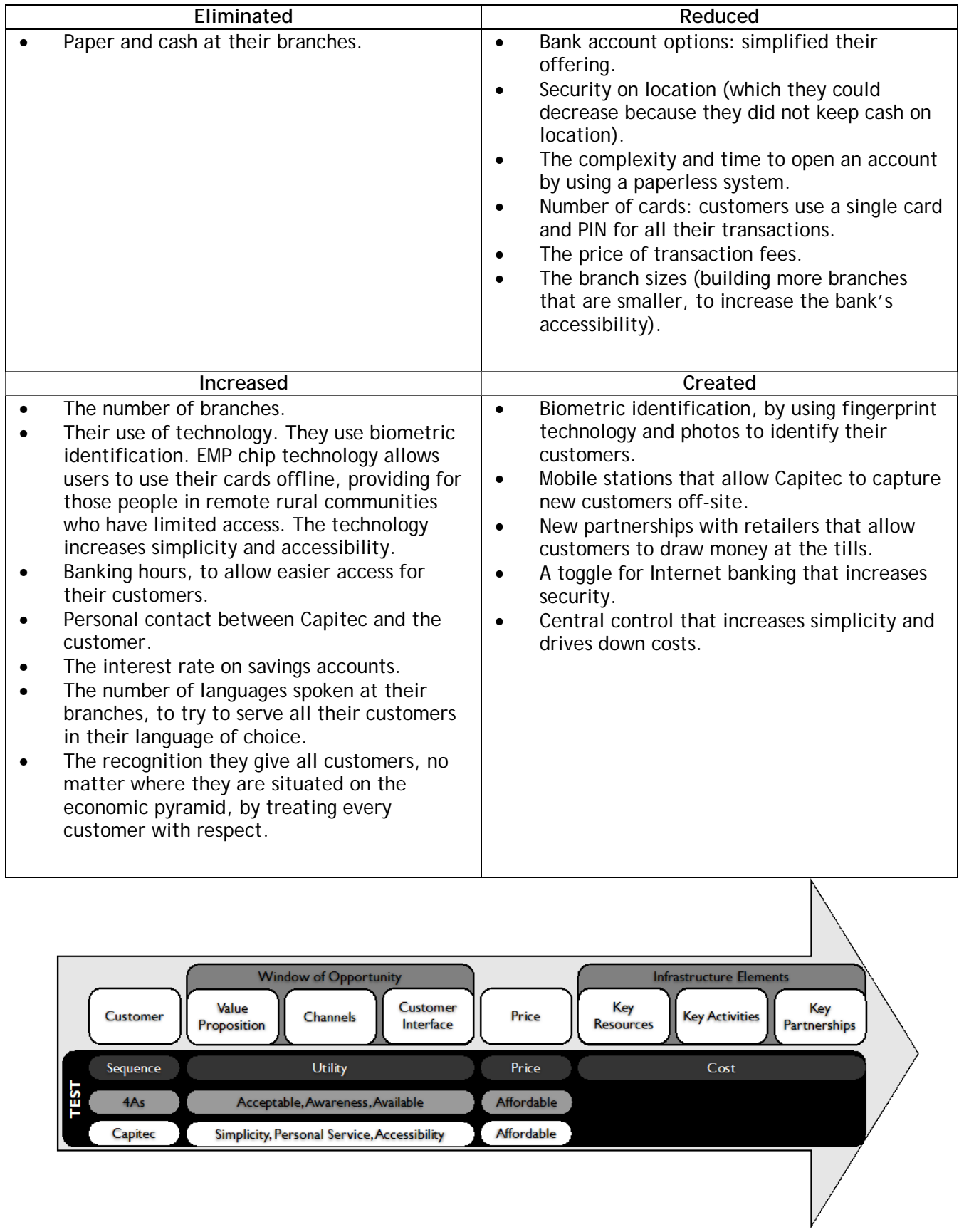

Figure 10: The Capitec case study sequence

\subsection{Customer strategy}

Prahalad [2] has stressed the fact that organisations must not only do research on the BoP market, but that they "must immerse themselves in the lives of their target market". In the case of the BoP, it is essential to start with an understanding of the customers in order to overcome constraints and correct the assumptions that have been made about the market. 
An organisation must clearly identify any assumptions and prejudices it has about the BoP, and go into the field with the goal of testing whether the assumptions and prejudices are true or not. Some of the limiting assumptions that organisations make that are disproved by the Capitec model include [2]:

- $\quad$ The BoP have no purchasing power;

- They are not brand conscious;

- They are hard to reach and are unable to use technology.

Example: Capitec's customer strategy

The founders of Capitec walked the streets of many townships, engaged with the people, gained insight into their lifestyles, and found out what their constraints were and why they don't use certain products [16]. They observed people using money, noticed where they spent most of their time, figured out why current banking services were not fulfilling the needs and core requirements of the BoP, and made an effort to understand their lifestyle. Capitec noticed that banking products were complicated and expensive, and the BoP could not access them. The BoP also lacked the confidence to engage with banks that generally treated them without respect.

The wine and liquor industry background of the founders of Capitec brings them unique insight into the BoP: the liquor merchants recognised that the collective BoP has a large spending power. They made an effort to understand their customers and their frustrations, and noticed that they have no access to affordable financial services [19]. By successfully targeting the BoP, Capitec disproved many assumptions about the BoP [15]:

- They do need financial services.

- There is a propensity for saving, if it is accessible.

- When the product is right and acceptable, the market can be served very profitably.

The BoP's perceptions of banks in the past were that they are expensive, they offer complicated products and services, and opening an account is difficult. Another perception was that a bank was not a place to grow your money. Capitec changed these perceptions by fulfilling the needs of the BoP.

Capitec targeted the non-customers who were previously unbanked. It added functionality to its offering by decreasing the price and increasing the value, simplicity, and accessibility of its products. It also increased the emotional appeal of the product by treating its customers with respect, and by simplifying the products and processes to ensure that customers never feel embarrassed by their lack of skills and education. Being involved in the brand gives them social status. Customers also have more power in negotiation, making them feel valued and in control [15].

\subsection{Window of opportunity}

The mission of the components in the window of opportunity is to ensure that the customer receives exceptional utility from the products and services that the organisation offers, while also ensuring that the organisation generates an appropriate revenue. It has three components.

\subsubsection{Value proposition component}

The value proposition is the first component of the window of opportunity. It describes all the products and services that the organisation offers its customers. It must be suitable to the needs of the BoP, and offer utility and value to them. The core requirement of the BoP for this building block is acceptability of the products and services.

Example: Capitec's value proposition

The BoP may lack basic skills, education, and literacy; Capitec has therefore simplified its offering, making the value proposition acceptable to the BoP. Opening a new account takes ten minutes and is a completely paperless process. All a potential customer needs is their green bar-coded ID document and proof of residence. The staff enters all information into the system [15], which means that the BoP does not have to be literate to open an account. This is a non-threatening process, designed to make the customer feel welcome and safe. Capitec offers a basic account, but it has the full functionality necessary for core banking. They offer a single standardised product range.

Another way in which Capitec offers its customers value is by automatically giving free account balances. They have realised that the first thing most customers check when they get to the ATM is their balance. Capitec also provides their customers with card readers at retailers where they can check their balance. This can eliminate the embarrassment customers might experience when they swipe their card at the cashier and find that they do not have a positive balance. Capitec is conscious 
of the fact that, for a poor person, it is utterly humiliating to be perceived as poor. When a highincome person's card doesn't work, they just take out another card and there is no humiliation, because their status is deeply rooted in more than perception alone $[15,16]$.

Customers receive a single card and PIN for all their accounts (a maximum of three) [16]. Capitec's debit card is designed with an embedded chip that allows its clients to conduct transactions even if the server is offline [19]. They developed the EMP chip technology in collaboration with MasterCard. This enables people in rural areas to transact without cash, no matter how remote the area, or whether they have a connection.

Capitec has developed a token for Internet banking that increases the security of Internet transactions. This product has had a slow take-up [15] with the BoP, because few people at the core could afford or use it. Capitec has realised that cellular phones are the future of banking, and is busy converting its Internet banking to more accessible channels by making use of even more accessible locations, and by using telecom banking [15].

Capitec's value proposition offers its customers status, simplicity, and good value. It fulfils the BoP's core requirements. Capitec offers a net positive return for its customers. Its fees are low, while the interest on savings is high. The interest outweighs the fees [15].

\subsubsection{Channels component}

Many of the BoP are illiterate, and therefore visual communication is very important. The core requirements of the channel component are awareness and availability.

The design of the channels component follows the value proposition. The channel component of the business model includes all the marketing and distribution activities that an organisation needs to fulfil in order to make potential customers aware of the product/service, and ensure that it is consistently available. Effective marketing and distribution channels are very important to ensure that an organisation can attract a large volume of clients; this is critical because the profit margin on each purchase is low at the BoP. Customers must therefore be attracted in large volumes, ensuring that the organisation can secure a large revenue.

\section{Example: Capitec's channels}

The core requirement that Capitec has identified for the channels component [15] is accessibility. Customers must be able to reach its branches, and they must know about the product. Capitec's core requirement, accessibility, corresponds with the awareness and availability components of the $4 \mathrm{~A}^{\prime} \mathrm{s}$.

Capitec has therefore provided a wide network of branches. It has increased the number of branches and decreased their size. By situating the branches close to each other, customers can be targeted more precisely [16].

Capitec has also introduced longer banking hours [19]. It has realised that BoP customers do not have the luxury of flexible time. Capitec has broken conventional practices by increasing accessibility.

Capitec ensures that its services are accessible by locating bank branches where the BoP needs them, namely [15]:

- Taxi ranks

- Train stations

- Townships

- $\quad$ Rural centres

It is difficult to make the BoP aware of a new product, because they often do not have access to traditional marketing infrastructure such as TV, radio, and print media. Initially, Capitec did not use above-the-line marketing [15]: it relied on word of mouth, and sent marketing 'hit squads' into townships to distribute leaflets and information. It also did brand awareness campaigning in and around townships. Capitec sponsored events such as union meetings and graduations in its target areas.

Capitec makes use of mobile stations that fit in a suitcase. These stations include a laptop with Internet connection, a camera, a fingerprint reader, and a card swiper. Capitec's sales teams go to factories and other organisations, bringing the bank to the people. They help workers to open accounts [15] in a non-threatening environment.

\subsubsection{Customer interface component}

When the value proposition and the channels have been designed, an organisation must focus its attention on the customer interface. The interface is the connection and 
interaction between the organisation and the customer. The customer interface component of the business model shows how the organisation connects and interacts with the customer.

The BoP are often first-time users who are intimidated by difficult and time-consuming procedures. An organisation must therefore develop plans, methods, and routines that make the buying experience easier and more enjoyable. The organisation must be approachable and inviting to ensure that customers who lack skills and who have cultural or language barriers are not anxious or frightened to approach the shop floor. The organisation must make itself acceptable by making all its customer processes easy, friendly, and straightforward.

Example: Capitec's customer interface

Simplicity and personal service are the key to Capitec's products and processes, making its customer interface more acceptable to the BoP. One of the biggest constraints that Capitec faces is the lack of confidence found in people with limited literacy and education. Personal care and simplicity is the main focus and core constraint of Capitec's interface. All its processes are designed to give its customers more control, while keeping costs down.

It makes sure that even customers with a low level of skills and education can use its products. It empowers its customers in negotiation, and gives them the control to make informed decisions about the fate of their fortune.

The customer interface at Capitec is paperless. This means that customers who are illiterate will not be intimidated when opening an account or using Capitec's products, because the tellers will assist them personally and fill in the online forms for them.

Biometric controls, such as fingerprint technology and cameras to take personal photos of each customer, improve security and ease of use [17]. The banking hours are extended from 8am to 5pm, allowing customers more flexibility and control to bank when they wish to [16].

Tellers are selected from the local community, and this allows them to understand their customers better [19]. Capitec's aim is to serve customers in their own language as far as possible. Tellers don't face customers through $40 \mathrm{~mm}$ of bulletproof glass $[16,15]$. This makes tellers seem more approachable, friendlier, and less intimidating.

Capitec tries to define its market by customer rather than by income. Its aim is to be status-neutral.

The big four banks show a divergence between value and status [15]. If a customer looks poor, the tellers treat them with disregard, as inferior, as if they were not valued customers. Their branches in poor communities are different from higher-class branches because there is an assumption that, for example, miners will not mind less 'flashy' branches because they are used to rough conditions. This view has led to great discrimination, and therefore to distrust and skepticism about banks. Capitec took a different approach. It made all its branches the same, no matter who its customers are. Personal service is incorporated, and each customer is treated importantly; the tellers are friendly and helpful, and never embarrass their customers [15].

\subsection{Price element}

The price component of the business model considers the price that will be affordable to the BoP to enable them to buy the product. It also looks at how an organisation makes money, and at its pricing model.

Kim and Mauborgne [20] argue that organisations must strategically price the product from the beginning, to ensure that the mass of buyers is captured. The price an organisation chooses must not only attract the mass market, but also assist the organisation to retain them. Kim and Mauborgne [10] call this the pricing strategy. The strategic price and the rapid brand recognition built by the organisation will discourage imitators, and make it very difficult to catch up to the economies of scale and learning advantages the organisation has gained. It makes the competition almost irrelevant. 
Example: Capitec's price

Capitec's lending interest rates and transaction fees are significantly lower than those of most other banks [16]. Capitec offers a zero cost on debit card purchases and free cash withdrawals from retailers [12]. Its fee structure is simple, and it offers a net positive return for its customers (due to its high savings interest rates), allowing them to grow their money [19].

\subsection{The infrastructure element}

The infrastructure element describes all activities and resources that create value for the customer and generate sales, as well as all the costs that an organisation incurs while operating its business model [5].

\section{Example: Capitec's infrastructure}

Capitec set the price of its value proposition at a level that the BoP can afford, and therefore needs to ensure that its operating costs are below the target cost to make sure that it makes its required profit. When strategic pricing drives the cost structure of an organisation, the key resources and activities of the business model must be set up from the beginning to be lean and profitable [10]. A good business model with a low cost structure is very difficult to imitate. The lower the costs that an organisation faces, the higher the profits it makes.

Capitec does not keep cash on the premises, which allows it to reduce costs by having less security and no bulletproof glass [16]. The central system, which enables branches not to have a back office, saves money. Capitec reduces costs by keeping its branches simple and by collaborating with partners who have the necessary infrastructure [19].

The following three components of the infrastructure element must be designed to assist an organisation to achieve its target cost while not compromising the value of its offerings:

\subsubsection{Key resources component}

The key resources component of the business model must consider how an organisation can reduce the total cost of the resources it uses in its products, processes, practices, and premises. This considers all the resources that the other components of the business model need and demand.

\section{Example: Capitec's key resources}

Technology is the cornerstone and most important resource of Capitec. Technology drives costs down while increasing customer value. It saves costs on infrastructure by using Windows servers instead of UNIX or mainframes [17]. Staff are trained internally to ensure that the standard is high, and this also reduces costs [16].

\subsubsection{Key activities component}

The key activities component describes all the activities that organisations complete to ensure that the business model operates effectively and efficiently.

Example: Capitec's key activities

Behind the scenes, at the heart of Capitec's operations, is a very centralised system in a centralised location. Capitec has developed a computer system that facilitates paperless and cashless transactions. The computer system is process-driven and decreases the cost and effort of banking [19]. Capitec uses Windows, which is a scalable and stable system. This means that there is less risk of system failure.

Branch costs are minimised by having a cashless bank [16]. Only deposits involve cash, and these go straight to the drop safe. Cash can only be drawn from ATMs or retailers, and not over the counter. Branch staff therefore do not have to worry about looking after cash, and can give their customers more personal attention. Security needs and costs are also decreased.

\subsubsection{Key partnerships component}

The key partnerships component is part of the cost of the business model, and describes the network of partners and suppliers the organisation needs to make sure its business model works most effectively.

Many organisations try to do all the manufacturing and distribution activities themselves. This can cause time delays, as Kim and Mauborgne [10] note: "Time works against the innovator in favour of the imitator". Organisations must realize that they are not the best 
at everything, and must rather look to outside organisations that can fill the gaps in their capabilities. Certain capabilities can be secured quickly and effectively through collaboration.

Other organisations' expertise, distribution channels, and economies of scale can be leveraged [8].

\section{Example: Capitec's key partnerships}

Capitec uses existing infrastructure wherever possible. It has increased its reach by collaborating with retailers like Pep, Pick $n$ Pay, Shoprite, and Checkers [16], and by using their infrastructure. It has extended its network of places where its customers can draw money without large infrastructure investments. It is a win-win situation: the retailers reduce their risk and the cost of transporting and storing their cash [19]. Capitec encourages its customers to draw cash from retailers by keeping its withdrawal fees low. It charges zero transaction fees for all debit card purchases at all retailers. It is also a secure way of making transactions in spaza shops in rural areas.

Furthermore, Capitec has collaborated with MasterCard to develop cards that allow customers to use them even if they are in remote areas, thus improving accessibility of the banking service.

\section{VALIDATION}

The validation of the research on a practical level does not lend itself to current time constraints, together with many factors that are out of the control of the author.

The validation of the research was done through expert analysis. Five experts from fields applicable to the study were chosen to determine (from the interviewee's perspective) whether the research was rational and could be successful. The goal of each interview was to find out to what extent the experts agreed with different aspects of the framework, together with motivations and recommendations.

All the interviewees agreed that the model was useful and that the framework would address the main reasons (assumptions, understanding, approach, design, and brand image loss) why organisations struggle to target the BoP.

It was stated with conviction that the framework would be successful, provided that it was correctly designed and implemented.

\section{CONCLUSION AND RECOMMENDATIONS}

The literature proves that the BoP can offer valuable opportunities for organisations that target them; however, the BoP's unique characteristics make them a difficult market to target. In this research, the 'bottom of the pyramid' literature, the business model canvas literature, and the blue ocean strategy literature were used to develop a framework that gives organisations guidelines on how to enter the BoP market. By designing a business model around the core requirements of the BoP and in the strategic sequence given by Kim and Mauborgne, this framework allows an organisation systematically to design a business model to target the BoP population.

The expert analysis provided excellent input and feedback that was used to shape and modify the framework, and to clarify the context in which it must operate - the BoP population. The interviews highlighted an important point, which was mentioned by the majority of the interviewees; a business should ideally have a foothold in a market, and only then address the BoP in that market.

In fact, companies can either adopt the framework as Capitec did - by venturing into the market directed at the BoP immediately - or they can expand their business by moving from their current market into the BoP space. In this latter case, the organisation can plan to leverage its current offerings to the rest of the pyramid, and determine how these offerings can be adapted to suit the needs of the BoP. 


\section{REFERENCES}

[1] Prahalad, C.K. 2006. The fortune at the bottom of the pyramid. Upper Saddle River, N.Y., Wharton School Publishing.

[2] Prahalad, C.K. 2006. The innovation sandbox. Strategy+Business, 44, 62.

[3] Linder, J.C. \& Cantrell, S. 2000. Changing business models: Surveying the landscape. Accenture Institute for Strategic Change, 1-13.

[4] Citibank. 2006. Building a business model for success. Citigroup, Inc.

[5] Osterwalder, A. \& Pigneur, Y. 2009. Business model generation. Self-published.

[6] Osterwalder, A. 2004. The business model ontology - A proposition in a design science approach. University of Lausanne.

[7] Christensen, C.M. 1997. The innovator's dilemma: When new technologies cause great firms to fail. Boston, MA: Harvard Business School Press.

[8] Kim, W.C. \& Mauborgne, R. 2005. Blue ocean strategy. Boston, MA: Harvard Business School Press.

[9] Porter, M.E. 1987. From competitive advantage to corporate strategy. Harvard Business Revue, 65(3), 43-59.

[10] Kim, W.C. \& Mauborgne, R. 2001. Knowing a winning business idea when you see one. J. Prod. Innovat. Manag. 18(2), 123.

[11] Anderson, J . \& Billou, N. 2007. Serving the world's poor: Innovation at the base of the economic pyramid. J. Bus. Strategy, 28(2), 14-21.

[12] Capitec Bank. Capitec website. 2010. Available at: http:// www.capitecbank.co.za/ . Accessed 9 J uly, 2010.

[13] Peacock, B. 2010. Finding a needle in a haystack. Available at: http:/ / www.timeslive. co.za/ business/ money/ article745940. ece/ Finding-the-needle-in-thehaystack. (Accessed 7 Nov 2010)

[14] Kim, W.C. \& Mauborgne, R. 2002. Charting your company's future. Harvard Business Review, 80(6), 76-85.

[15] Lee, G. 2009-2010. Capitec Bank: Interview.

[16] McNulty, A. 2009. Behind Capitec's successful model. Available at: http:/ / www. leader. co.za/ article. aspx?s=1\&f=1\&a=1650. Accessed November 16, 2010.

[17] Caruthers, R.W. 2006. Capitec banks on South Africa's underserved. Available at: http:/ / www. windowsfs. com/ special-features/ capitec-banks-on-south-africa's-underserved. Accessed February 17, 2010.

[18] Coetzee, G. 2003. Innovative approaches to delivering microfinance services: The case of Capitec Bank. Microsave. Available at: http:// www. microsave.org/research_paper/innovativeapproaches-to-delivering-microfinance-services-the-case-of-capitec-bank. Accessed February 17, 2010.

[19] Planting, S. 2006. Assume you can. Available at: http:/ / free.financialmail.co.za/ innovations/ 06/ 0407/ cinn.htm. Accessed February 17, 2010.

[20] Kim, W.C. \& Mauborgne, R. 1999. Strategy, value innovation, and the knowledge economy. Sloan Management Review, 40, 41-54 